$\left.\begin{array}{c}\text { Sournals } \\ \text { INTERNATIONAL JOURNAL OF } \\ \text { ORGANIZATIONAL LEADERSHIP }\end{array}\right) \begin{gathered}\text { INDUSTRIAL } \\ \text { MANAGEMENT } \\ \text { INSTITUTE }\end{gathered}$

\title{
Role of leader-member exchange relationship in organizational change management: Mediating role of organizational culture
}

\author{
Muhammad Arif $^{*}$, Sarwar Zahid ${ }^{2}$, Uzma Kashif ${ }^{3,}$ Muzammal Ilyas Sindhu ${ }^{4}$ \\ ${ }^{1,2}$ Associate Professor, Bahria University, Islamabad Pakistan \\ ${ }^{3}$ Lecturer, COMSATS, Islamabad Pakistan \\ ${ }^{4}$ Ph.D Scholar, Bahria University, Islamabad Pakistan
}

\begin{abstract}
Keywords:

LMX, Organizational Change Management, Organizational Culture

\section{Received}

08 June 2016

Received in revised form 02 October 2016

Accepted

Today's dynamic and global village enforces competitive organizations to adopt new practices, processes, and regulations for survival. This study examined the role of leadermember exchange relationship in organizational change management with mediating role of organizational culture. Supervisors have contributing role to implement the changes. Middle and front line managers have more discretionary power to implement further changes for having better performance. The findings of this study showed that there exist significant and positive relationship between LMX and organizational change management. Furthermore, it is also depicted that organizational culture show mediation between LMX and organizational change management.
\end{abstract}

14 October 2016

Correspondence:

arifkhattak78@gmail.com

(C)AIMI Journals

Leader-member exchange (LMX) theory indicates relationship between supervisor and employee. LMX argues that there is direct relationship between interactions of supervisoremployee and performance. Both parties start to share information, resources, time, and emotional effort, which provides employee to give more autonomy in decision-making and control over workplace (Wang, Law, Hackett, Wang, \& Chen, 2005). Tummers and Knies (2013) find that there is positive relationship between managers and employees in public sector 
organization that leads to more organizational commitment, higher work effort, and enriched empowerment. Effective LMX plays an important role at all levels of the organization. All stakeholders gain benefit as LMX relationship is established (Mueller \& Lee, 2002). Supervisor and subordinates play an important role in development and maintenance of a proactive engineering asset management organizational culture (PEAMOC). Both may be influenced by their attitude toward change and employee autonomy (Brunetto, Farr-Wharton, Shacklock, \& Robson, 2012). LMX relationships can accordingly be expected to play an important role in maintaining PEAMOC.

Poor quality LMX relationships reduce the preemptive behavior of employees and bring about less commitment and responsive engineering asset management. Realizing the need for more confirmatory research, a new study by Brunettoet, Xerri, \& Nelson (2013) gives approval that a lack of support, information, and resources prevents the ability of employees to work effectively in engineering asset management organizations and this leads to explaining the occurrence of reactive cultures in engineering asset management organizations. Global business environment is constantly growing where change has become an important source of success and existence. Public and private sector organizations are constantly trying to survive in today's dynamic competitive environment (Ackoff, Magidson, \& Addison, 2006; Burnes, 2004; Hailey \& Balogun, 2002; Kotter, 1996; Mintzberg, 1979; Moran \& Brightman, 2000).

Today, successful change management is a major topic for all organizations and how to successfully achieve organizational change is the provocative question and it gained more fascination during economic crises and numbers of questions are being asked by many organizations (Ashurst \& Hodges, 2010). The organization needs to identify the environmental conditions required for the change plan to succeed (Hotek \& White, 1999; Kotter, 1996). P. S. Weber and J. E. Weber (2001) argue that people's perception of organizational readiness for change can also affect change success. Organizational readiness for change has been defined as the organizational members, change commitment, and self-efficacy to implement organizational change (Weiner, 2009). The positive attitude and strong commitment to change are main outcomes of the readiness to change (Rafferty, Jimmieson \& Armenakis, 2013).

According to L. A. Anderson and D. Anderson (2010), content, people, and process are considered as main aspects of change. Content refers to the strategy, systems, technologies, and work practices. Technology is important source to drive change and it plays a strategic role in facilitating change and making it part of the organizational culture. People refers to human and human behavior which is considered important for implementing organizational change that is also known as personal change. The deeper the organizational change, the more important for people to alter their own values and perspectives to align with overall organizational perspective (Moran \& Brightman, 2000). Van den Heuvel, Demerouti, and Bakker (2014) argue that in order to increase the probability of change success, more attention needs to be given to the people. The third aspect of change is process which signifies actions and procedures to implementation of change. Communication and regular meetings with employees facilitates implementing change (Van den Heuvel et al., 2014). Interaction between content, people, and process is an indication of successful change.

In current globalization success a factor of any organization depends not only on proper usage of resources and broader strategies (Schein, 2010) but organizational culture plays an 
important role in achieving its real goals. Equal job opportunities and workforce diversity gathered various manpower under one roof (Hartnell, Ou, \& Kinicki, 2011) which is assigned to different norms and values. Such workforce diversity develops organizational culture in which managers play a role of constraint to overcome these variations which will lead to make sure of organizational performance.

The purpose of this study is to investigate the role of a leader-member exchange in organizational change management. Moreover, organizational culture plays mediating role between LMX and organizational change management. The rationale of this study is the previous research gap proposed by Tariq, Mumtaz, Ahmad, and Waheed (2014) who persuaded to explore impact of leader-member exchange on organizational performance and commitment with organizational culture as moderator. This study intends to fill that gap to appraise the knowledge. Following this, the current study contributes to take decision about their investment and to make understanding about the behavior of investors to the management. Investors can understand the positive or negative relationship about the organization change management in developing future strategies or policies. This study will also tell us about behavior that is favorable to decision makers. In addition, managers can take benefit to develop relationship that is more attractive to decision makers.

\section{The Literature Review}

\section{Leader-Member Exchange Theory}

Leader-member exchange theory was developed by Graen, Novak, and Sommerkamp (1982). The theory emphasizes on the relationship between a leader and other members of a work unit, team, department, or an organization. This discusses those exchanges of leaders with their subordinates result in different relationships, the quality of which influences individual and organizational performance. It also indicates that leaders have limited time, authority, and resources to discuss different issues, so they cannot build similar relations with all members (Bauer \& Green, 1996). Therefore, this theory indicates different methods to a leader to develop different leadership styles with multiple subordinates.

There comes building of different types of in-group and out-group members and shows ranges of relationships from low to high quality (Deluga \& Perry, 1994). In-group members are facilitated with different types of benefits and rewards like promotions, favorable performance appraisals, and support in their career development (Deluga \& Perry, 1994), influence in decision making, increased job attitude, and open communication (Case, 1998), and beyond their job agreements (Dockery \& Steiner, 1990). This better relationship leads to building a good team and gaining hardworking subordinates that perform their responsibilities actively (Deluga \& Perry, 1994). Employees in high-quality LMX relationships work in a more resourceful work environment and in succession, that makes work engagement and job performance easier (Breevaart, Bakker, Demerouti, \& van den Heuvel, 2015). In contrast, outgroup members have relatively low quality in building strong relationship which leads to low trust, less support, infrequent interaction, and less reward and benefits (Wilhelm, Herd, \& Steiner, 1993). These members also show less job satisfaction which leads to more turnovers (Schriesheim, Neider, \&Scandura, 1998). 
Leader-member exchange theory is combination of role theory and social exchange theory. Role theory emphasizes on the roles of leaders and member (Hofmann, Morgeson, \& Gerras, 2003) while social exchange theory have concentration on exchanges in between leader and members. Members in organization perform their duties after assuming their roles (Graen, 1976), so role theory can help to understand how this role-development process is working in leader-member exchange theory (Dienesch \& Liden, 1986). Tariq et al (2014) found a significant and positive relationship between leader-member exchange, organizational performance, and commitment.

\section{Organizational Change}

Global business environment has dynamic position and for their existence and success, organizations have to modify their policies, rules, and regulations with the change in organizational structure, managerial and non-managerial conflicts, and changes in ownership structures. Organizations have to move toward more dynamic rules instead of old generations with much managerial control and information system (Christiansen \&Varnes (2015). Zhao, (1993) suggested that rule formation and rule change is performed into two different methods. The rule formation come into existence due to external factors like shocks and crisis but the rule change process is due to an internal learning process. March, Schulz, \& Zhou, (2000) found that rule formation is a result of organization's size and complexity of organizations structures. Beck and Kieser (2003) found that major change in a bank's rule is relevant to organizational change which leads to make that organization more knowledgeable and organized.

Ackoff et al. (2006) focused on different plans and procedures which plays role in managing change. Multiple authors provide guidance to manage change which is incremental change. Mintzberg (1979) and Miller (1982) defined the regular fluctuation in strategies as an incremental change. Miller (1982) focused to adopt most economical and cost oriented change strategies during revolutionary periods of change. It is very stressful to manage change and its interconnected uncertainties which require a lot of physical, emotional, and psychological tolls (McCaskey, 1982).

\section{Organizational Culture}

Organizational culture is a set of traits and behaviors of internal stakeholders through which they can not only perceive and think about their internal environment but also can cope with the externally interconnected issues. Current organizational culture must be transferred to new entrants, so that they will be able to follow organizational philosophy (Schein, 2010). Avolio, Zhu, Koh, and Bhatia (2004) described the importance of organizational culture for transferring the current state of norms and values to new incoming persons which is known as socialization process. Involvement, consistency, and mission can increase the productivity and performance of an organization.

Ogbonna and Harris (2000) discussed three dimensions in their studies about leadership, culture, and organizational performance. Here organizational culture is performing as a mediating role between leadership and organizational performance whereas organizational culture also fluctuates to organizational performance. Silverthorne (2004) found in his studies 
that culture has a moderating role in between leadership and job satisfaction as well as job commitment. There is a positive relationship between job commitment and organizational objectives which is the key duty of leader (Lok \& Crawford, 1999).

\section{The Study}

\section{Theoretical Framework}

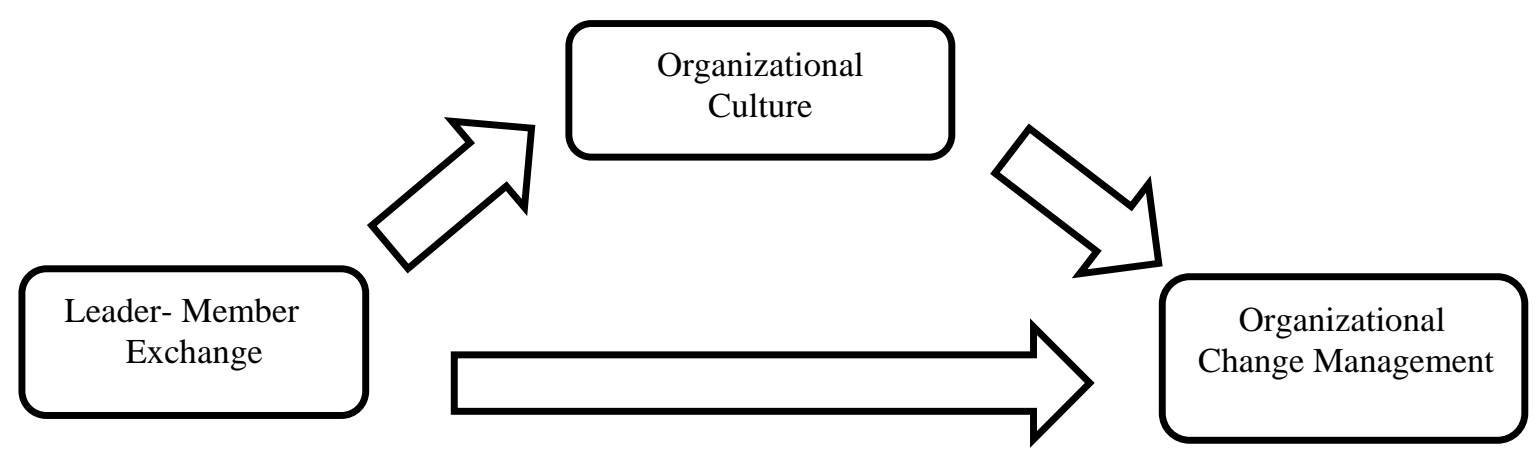

Figure 1. Theoretical framework of the study

This framework has been suggested by Tariq et al. (2014) in their studies as future research path but the mediating role has been found in the above discussed literature.

The following hypotheses guided the study:

$\mathbf{H}_{\mathbf{1}}$ : There is a significant relationship between leader-member exchange and change management.

$\mathbf{H}_{2}$ : There is association between leader-member exchange and organizational culture.

$\mathbf{H}_{3}$ : There is a relationship between organizational culture and organizational change.

\section{Method}

The target population of this study was employees of financial and non-financial organizations. Sample size consisted of 185 employees belonging to banking, sales and distributions, and telecommunication and teaching organizations. This study used stratified sampling technique which falls in probability sampling for selection of respondents. Stratified sampling technique has main feature in which samples can be stratified upon the basis of revenues, size, turnover etc.

Sales and distribution, banking and education industry is accessible to researcher in which those persons were selected for sample which is working on a managerial post. One questionnaire was given to each respondent and they were requested to fill while researchers were around to help in case of feeling difficulty in understanding. All the questionnaires were filled in personal observation due to some reasons. First of all it helped to answer the queries and secondly to keep the responses unbiased up to some extent.

Leader-member exchange relationship was measured by using a scale developed by Scandura and Grain (1984). Scale for the measurement of organizational change management developed by Zamor (1998) came into use. Organizational culture was measured by using scale 
developed by Hofstede, Neuijen, Ohayv, and Sanders (1990). In the present study, five Likert Scale was used to attain the responses of respondents in case of all variables. Following this, scale rating is categorized as $5=$ strongly agree, $4=$ =agree, $3=$ =neutral, $2=$ disagree, $1=$ strongly disagree.

\section{Results}

In this study, the results which were obtained from data collected from our respondents regarding leader-member exchange, organizational change, and organizational culture were analyzed. SPSS software was used for descriptive statistics, reliability test, correlation analysis, regression analysis, mediating effect, and structural equation modeling. Values of Cronbach's Alpha for LMX, organizational change, and organizational culture were 0.731, 0.765, and 0.672, respectively. Demographics include gender, age, qualification, experience of respondents and type of employer.

\section{Descriptive Statistics}

Table 1 represents the descriptive statistics which indicates the normality of data. Considering Table 1, mean indicates average of data while minimum and maximum show extreme responses; standard deviation indicates the spread of data; and skewness and kurtosis represent normal distribution of responses.

Table 1

Descriptive Statistics

\begin{tabular}{llllllll}
\hline & $\mathrm{N}$ & Minimum & Maximum & Mean & SD & Skewness & Kurtosis \\
\hline LMX & 185 & 2.00 & 4.83 & 4.046 & 0.525 & -0.805 & 0.768 \\
CM & 185 & 2.13 & 4.75 & 3.950 & 0.523 & -0.895 & 1.095 \\
OC & 185 & 3.00 & 5.00 & 4.191 & 0.428 & -0.254 & -0.472 \\
\hline
\end{tabular}

\section{Correlation}

Correlation matrix indicates the relationship between predicted and predictor variables as well as predictors itself. Correlation is not considered as a strong indication of in between relations in modern age but in the earlier times, it was considered as best source. This correlation is followed by regression comparatively. Furthermore, this relationship is supported by Pearson Correlation in which the values indicated that there exist significant and positive relationship between LMX and organizational culture at 95\% confidence interval and between LMX and organizational change at 99\% confidence interval. Moreover, organizational culture and organizational change also showed significant relation at 99\% confidence interval. In these relations, one thing which is notified is that there exist no such like strong relations which could be indication of autocorrelation in between the predictor variables. Table 2 shows correlations. 
Table 2

Correlations

\begin{tabular}{lllll}
\hline & & LMX & OC & CM \\
\hline \multirow{3}{*}{ LMX } & Pearson Correlation & 1.000 & & \\
& Sig. (2-tailed) & & & \\
OC & N & 185 & 1.000 & \\
& Pearson Correlation & $0.162^{*}$ & & \\
& Sig. (2-tailed) & 0.027 & 185 & 1.000 \\
CM & N & 185 & $.156^{*}$ & \\
& Pearson Correlation & $.194^{* *}$ & 0.034 & 185 \\
\hline
\end{tabular}

*Correlation is significant at the 0.05 level

**Correlation is significant at the 0.01 level

\section{Regression Analysis}

Linear regression analysis has used for checking the impact of LMX on organizational change whereas organizational culture acted as a mediator. Here, data is obtained from banking, education, sales, and distribution sectors. It is an overall analysis. Value of R-square showed the change in dependent variable due to change in independent variable. Significant value of Fstatistics confirmed that this model showed goodness and fitness of model. Table 3 exhibits the model summary.

Table 3

Model Summary

\begin{tabular}{lllll}
\hline Mode & R-Square & F-Statistics & Sig. & Durbin-Watson \\
\hline 1 & 0.162 & 4.96 & 0.027 & \\
2 & 0.236 & 5.345 & 0.006 & 2.006 \\
\hline
\end{tabular}

Accordingly, 23.6\% of organizational change management is explained by leader-member exchange by showing the good and fitness of model at 0.006 p-value. Durbin Watson makes confirmation that there exists no issue of autocorrelation between the variables. Table 4 presents the coefficients.

Table 4

Coefficients

\begin{tabular}{llllll}
\hline & Model & Beta & Std. Error & t-value & Sig. \\
\hline 1 & Constant & 3.410 & .283 & 12.06 & .000 \\
& LMX & .150 & .067 & 2.227 & .027 \\
2 & Constant & 2.833 & .371 & 7.643 & .000 \\
& LMX & .125 & .067 & 1.857 & .065 \\
& OC & .172 & .073 & 2.368 & .019
\end{tabular}

Dependent Variable (CM) 
Results of regression analysis indicated that there exist significant and positive relationship between leader-member exchange relationship and organizational change. There can be positive changes in organizational policies, rules, and regulations with better relationship between leader and members. It is depicted that one unit change in LMX leads to 0.150 unit change in organizational change management. It is indicated that as this relationship between manager and his subordinates goes on positivism and favorability, it will show better impacts on its changing. Then decision makers will formulate such type of regulations which are favorable and easily implementable. Such positive relation will give confidence to the subordinates and then they will prefer to implement as soon as possible in good ways. Such thing also has been observed in historical and practical situations. Good governance, LMX, and flexible policies lead to providing better results in form of organizational performance. In the further analysis where organizational culture is playing mediating role, it has shown that one unit change in LMX and OC will lead to 0.125 and 0.172 variations in organizational change management, respectively. These finding depicted that better relations as well as organizational culture lead to organizational change.

\section{Conclusion}

The purpose of this study is to find the role of leader-member exchange relationship in organizational change management with mediating role of organizational culture. The findings revealed that there exists significant and positive relationship between LMX and organizational change management. Furthermore, it is also stated that organizational culture show mediation between LMX and organizational change management.

The present study has implications in both practical and theoretical aspects. As far as the theoretical aspect has been concerned, this study not only highlights the importance of leader member relationship at workplace but also enlightens the positive impacts of good relations on organizational policy formations. Moreover, managers can get benefits by making cultural aspects which is favorable to favorable organizational change management. Other than theoretical aspect, leader-member relationship could be considered as predictor of better rules and regulations for organizations.

Due to lake of time and resources, this study has been conducted only on banking, education, sales, and distribution industry mostly relating to Pakistani areas. Future research can be conducted involving more sectors including trading, service, and manufacturing sectors. Sample size was also small for this study; to this end, in future studies, it can be extended for conducting more comprehensive studies. Furthermore, future studies can be made by considering both moderator and mediator.

\section{References}

Ackoff, R. L., Magidson, J., \& Addison, H. J. (2006). Idealized design: How to dissolve tomorrow's crisis... today. Upper Saddle River, NJ: Wharton School Publishing.

Anderson, L. A., \& Anderson, D. (2010). The change leader's roadmap: How to navigate your organization's transformation. New York: John Wiley \& Sons.

Ashurst, C., \& Hodges, J. (2010). Exploring business transformation: The challenges of developing a benefits realization capability. Journal of Change Management, 10(2), 217-237. 
Avolio, B. J., Zhu, W., Koh, W., \& Bhatia, P. (2004). Transformational leadership and organizational commitment: Mediating role of psychological empowerment and moderating role of structural distance. Journal of Organizational Behavior, 25, 951-968.

Bauer, T. N., \& Green, S. G. (1996). Development of leader-member exchange: A longitudinal test. Academy of Management Journal, 39(6), 1538-1567.

Beck, N., \& Kieser, A. (2003). The complexity of rule systems, experience and organizational learning. Organization Studies, 24(5), 793-814.

Breevaart, K., Bakker, A. B., Demerouti, E., \& van den Heuvel, M. (2015). Leader-member exchange, work engagement, and job performance. Journal of Managerial Psychology, 30(7), 754-770.

Brunetto, Y., Farr-Wharton, R., Shacklock, K., \& Robson, F. (2012). Supervisor relationships, teamwork, role ambiguity and discretionary power: Nurses in Australia and the United Kingdom. International Journal of Public Administration, 35(8), 532-543.

Brunetto, Y., Xerri, M., \& Nelson, S. (2013). Building a proactive, engagement culture in asset management organizations. Journal of Management in Engineering, 30(4), 1-9.

Burnes, B. (2004). Managing change: A strategic approach to organizational dynamics. New York: Pearson Education.

Case, R. (1998). Leader member exchange theory and sport: Possible applications. Journal of Sport Behavior, 21(4), 387-395.

Christiansen, J. K., \&Varnes, C. J. (2015). Drivers of changes in product development rules: How generations of rules change back and forth. European Journal of Innovation Management, 18(2), 218-237.

Deluga, R. J., \& Perry, J. T. (1991). The relationship of subordinate upward influencing behaviour, satisfaction and perceived superior effectiveness with leader-member exchanges. Journal of Occupational Psychology, 64(3), 239-252.

Deluga, R. J., \& Perry, J. T. (1994). The role of subordinate performance and ingratiation in leader-member exchanges. Group \& Organization Management, 19(1), 67-86.

Dienesch, R. M., \& Liden, R. C. (1986). Leader-member exchange model of leadership: A critique and further development. Academy of Management Review, 11(3), 618-634.

Dockery, T. M., \& Steiner, D. D. (1990). The role of the initial interaction in leader-member exchange. Group \& Organization Management, 15(4), 395-413.

Graen, G. B. (1976). Role making processes within complex organizations. In M. D. Dunnette (Ed.), Handbook of industrial and organizational psychology (pp. 1201-1245). Chicago: Rand-McNally.

Graen, G. B., Novak, M. A., \& Sommerkamp, P. (1982). The effects of leader-member exchange and job design on productivity and satisfaction: Testing a dual attachment model. Organizational Behavior \& Human Performance, 30(1), 109-131.

Hailey, V. H., \& Balogun, J. (2002). Devising context sensitive approaches to change: The example of GlaxoWellcome. Long Range Planning, 35(2), 153-178.

Hartnell, C. A., Ou, A. Y., \& Kinicki, A. (2011). Organizational culture and organizational effectiveness: A meta-analytic investigation of the competing values framework's theoretical suppositions. Journal of Applied Psychology, 96(4), 677-694.

Hofstede, G., Neuijen, B., Ohayv, D., \& Sanders, G. (1990). Measuring organizational cultures: A qualitative and Quantitative study across twenty cases. Administrative Science Quarterly, 35, 286-316

Hotek, D. R., \& White, M. R. (1999). An overview of performance technology. The Journal of Technology Studies, 25(1), 4350 .

Kotter, J. P. (1996). Leading change. Boston, Mass: Harvard Business School Press.

Lok, P., \& Crawford, J. (1999). The relationship between commitment and organizational culture, subculture, leadership style and job satisfaction in organizational change and development. Leadership \& Organization Development Journal, 20(7), 365-374.

March, J. G., Schulz, M., \& Zhou, X. (2000). The dynamics of rules: Change in written organizational codes. Stanford, CA: Stanford University Press.

McCaskey, M. B. (1982). The executive challenge: Managing change and ambiguity. London: Harpercollins College Div.

Miller, D. (1982). Evolution and revolution: A quantum view of structural change in organizations. Journal of Management studies, 19(2), 131-151.

Mintzberg, H. (1979). Patterns in strategy formation. Management Science, 24(9), 934-948.

Moran, J. W., \& Brightman, B. K. (2000). Leading organizational change. Journal of Workplace Learning, 12(2), 66-74. 
Mueller, B. H., \& Lee, J. (2002). Leader-member exchange and organizational communication satisfaction in multiple contexts. Journal of Business Communication, 39(2), 220-244.

Ogbonna, E., \& Harris, L. C. (2000). Leadership style, organizational culture and performance: Empirical evidence from UK companies. International Journal of Human Resource Management, 11(4), 766-788.

Rafferty, A. E., Jimmieson, N. L., \& Armenakis, A. A. (2013). Change readiness: A multilevel review. Journal of Management, 39(1), 110-135.

Scandura, T. A., \& Graen, G. B. (1984). Moderating effects of initial leader-member exchange status on the effects of a leadership intervention. Journal of Applied Psychology, 69(3), 428-436.

Schein, E. H. (2010). Organizational culture and leadership. San Francisco, CA: John Wiley \& Sons.

Schriesheim, C. A., Neider, L. L., \& Scandura, T. A. (1998). Delegation and leader-member exchange: Main effects, moderators, and measurement issues. Academy of Management Journal, 41(3), 298-318.

Silverthorne, C. (2004). The impact of organizational culture and person-organization fit on organizational commitment and job satisfaction in Taiwan. Leadership \& Organization Development Journal, 25(7), 592-599.

Tariq, U., Mumtaz, R., Ahmad, H. M., \& Waheed, A. (2014). Impact of leader member exchange on organizational performance and commitment with organizational culture as moderator: A non-monetary tactic to enhance outcome. International Journal of Scientific \& Engineering Research, 5(2), 92-100.

Tummers, L. G., \& Knies, E. (2013). Leadership and meaningful work in the public sector. Public Administration Review, 73(6), 859-868.

Van den Heuvel, M., Demerouti, E., \& Bakker, A. B. (2014). How psychological resources facilitate adaptation to organizational change. European Journal of Work \& Organizational Psychology, 23(6), 847-858.

Wang, H., Law, K. S., Hackett, R. D., Wang, D., \& Chen, Z. X. (2005). Leader-member exchange as a mediator of the relationship between transformational leadership and followers' performance and organizational citizenship behavior. Academy of Management Journal, 48(3), 420-432.

Weber, P. S., \& Weber, J. E. (2001). Changes in employee perceptions during organizational change. Leadership \& Organization Development Journal, 22(6), 291-300.

Weiner, B. J. (2009). A theory of organizational readiness for change. Implement Science, 4(1), 67-75.

Wilhelm, C. C., Herd, A. M., \& Steiner, D. D. (1993). Attributional conflict between managers and subordinates: An investigation of leader-member exchange effects. Journal of Organizational Behavior, 14(6), 531-544.

Zamor, R. L. (1998). Measuring and improving organizational change readiness in the libertyville fire department. Emmitsburg, MD: National Fire Academy.

Zhou, X. (1993). The dynamics of organizational rules. American Journal of Sociology, 98(5), 1134-1166. 